\title{
Analysis of Yvonne Owuor's Dust from the Perspective of Socialist Realism Literary Theory
}

\author{
Yonas Adamu Chernet \\ Department of Foreign Languages and Literature, College of Humanities, Language Studies, Journalism and Communication, Addis Ababa \\ University, Addis Ababa, Ethiopia
}

Email address:

yonasadamu6@gmail.com

\section{To cite this article:}

YonasAdamuChernet. Analysis of Yvonne Owuor's Dust from the Perspective of Socialist Realism Literary Theory. Arabic Language, Literature \& Culture. Vol. 6, No. 3, 2021, pp. 70-76. doi: 10.11648/j.allc.20210603.13

Received: July 9, 2021; Accepted: July 27, 2021; Published: August 9, 2021

\begin{abstract}
This study entitled Analysis of Yvonne Owuor's Dust from the Perspective of Socialist Realism Literary Theory attempts to read a Contemporary Anglophone Kenyan novel through the lens of Socialist Realism. Socialist Realism appeared for the first time in a speech of 17th May 1932 by Ivan Gronsky, and gaining worldwide recognition with postcolonial literary works, has been a focal point of different scholarly studies. In Kenya, the author such as Ngugi wa Thiong'o wrote literary works which can be seen in Socialist Realist eyes. The motivations behind taking up this topic are to fill the research gap in reading a novel from Kenya and to observe the trend in the practice of Socialist Realism. The paper aims to show the reemergence of Socialist Realism literary theory and the presence of Socialist Realist authors; after it was considered an outdated literary theory. And how the novelist from Kenya has applied the features that Socialist Realism is known. One novel has been chosen for this study, Dust. The novel was published after 2000 G.C. To read the novel, the theoretical framework forms at using Socialist Realism different features theorized by critics. The study concludes by finding major features of Socialist realism in the novel. These are optimism, socialist Humanism, class-ness, people-ness, Romanticism and positive hero. And the novelist in Kenya used Socialist Realism associating it with their contexts, connecting it with their respective historical background, shared current statues, commenting on existing economic, social, and political situations.
\end{abstract}

Keywords: Socialist Realism, Optimism, Socialist Humanism, Romanticism, Class-Ness, People-Ness, Positive Hero

\section{Introduction}

Background of the Study

Socialist Realism is a social force that is imitated by Kenyan authors from Westerns since Ngugi's era. The term Socialist Realism appeared for the first time in a speech of 17th May 1932 by Ivan Gronsky, chairperson of the Organizing Committee of the Union of Writers, then in process of formation. [6]

The socialist view is not new in the evolution of African fiction. In Kenya, a social vision was present in the work of Ngugi wa Thiong'o from the first. Although his endorsement of socialist principles and the patent influence of Marxism on his work come across most strongly in works like Petals of Blood (1977) and Devil on the Cross (1982), written after his celebrated novel A Grain of Wheat (1967).

Merriam-Webster Dictionary defines Socialist Realism as a Marxist aesthetic theory calling for the didactic use of literature, art, and music to develop social consciousness in an evolving socialist state. However, Abiye [2] mentioned that some societies are in the capitalist formation and experiencing its highest form called imperialism. As a result, after 40 years, many African countries are in the capitalist system. The end of the 19th and the beginning of the 20th century was theperiodofcapitalism.

However, Kenya is following the Capitalist system, but this system has its deficiency which was criticized by Socialist Realist authors recently. The novel Dust can be an example of such experiences. And the famous authors, who are based in Kenya, like Ngugi Wa Thiong'o was the writer of the Socialist Realism literary approach. [2]

As a result, the central concern of this paper was to assess the extent to which Socialist Realism literature seems to have been imitated from Westerns by Kenyans and still its continuity in Kenyan literary discourse in matters such as thematic concerns, ideologies, and methodology in the novel 
Dust. And the paper focused on showing the re-emergence of Socialist realism in contemporary Anglophone Kenyan novels.

\section{Methodology of the Study}

Socialist Realism is understood as a method in the art. The term 'method 'implies a mode of procedure. Procedure in any field may be set down in terms of specific steps or assets of rules. In the good and well-articulated literature, the subject of Socialist Realism asset of rule can be found, stated with a variety of emphases but capable, perhaps, of being compactly defined. The Soviet definitions of socialist realism employ a system of standard concepts which are by the nature sufficiently open to leave a great deal of room for the expression of the personality of each practitioner in this school of literature. A. I. Revyakin, [4]

Besides, the researcher used a qualitative research approach for analyzing the novel Dust. Qualitative research may involve a range of data collection instruments such as storytelling, narratology, thematic perception, and the like. The research also used the deconstructionist reading approach which helps to find out the literal and the underlying meanings of the text. And through the process, he investigates Socialist Realism ideologies and practices which are found in the novel.

As the analysis of the study, the researcher focuses on the novel, Yvonne Owuor's "Dust" which is published in 2015. For analysis, theoretical sources relevant to the topic scrutiny were gathered first. In this phase, the researcher of this research collected relevant literature on critical works on Socialist Realism literary theory together with some other useful local and international researches. To make the analysis clear and resourceful, the researcher focuses on important extracts that reveal the Socialist Realism ideology from the novel. Finally, analysis and interpretation of the extracts are making to arrive at certain findings and conclusions.

\subsection{Research Design}

Yonas [15] discussed literary work is built from several aspects and elements. To interpret a literary work appropriately, it needs appropriate theory and methodology relating to those elements. Methods and approaches in literary criticism function as a means to make the study easier. This research was literary criticism to criticize means to analyze, interpret and evaluate literary work.

\subsection{Data Sources}

As this research requires complicated data and references, the researcher briefly collects the primary data Yvonne Owuor's Dust on the other hand, secondary sources will be the reading materials, which write about Socialist Realism, help the researcher to shape the conceptual framework for the study.

\section{Result and Discussion}

\section{Socialist Realism in the novel Dust}

For the study, the researcher has chosen the most important work of Yvonne Owuor's Dust which was written in 2014. The African novel from the time of colonialism to the present day; has been engaged in exposing and criticizing the predicaments Africa faces on many levels. The class-ness, civil wars, partisanship, positive heroes, people-ness, optimism, maladministration, corruption, and Socialist humanism are among the issues being raised in the selected novel. Discussed by aspects with specific themes, the African novel has evolved to what it has become in the present day.

As a result, under this part of the study, the researcher discussed major aspects of Socialist Realism in the novel Dust. These features are Optimism, positive hero, humanity, romanticism, class-ness, and peopleness. Abiye [2] discussed all these aspects in his thesis.

\subsection{Optimism in the Novel Dust}

As Herman Ermolaev [10] discussed, the basic demand that we make on the writer is: write the truth and portray truthfully our reality that is in itself dialectic. So in those selected novels, the authors used the truth and the reality of the country. Yvonne AdhiamboOwuor's Dust has many optimistic features associated with Socialist Realism. Optimism is having and making a bright future for coming to Kenya, after the 2007 election. The author discussed a common consensus about coming to Kenya.

Blended cultures, In toxicating fusion-the new revised Kenya; Bead Kofia on his head, cloaked, fly-whisky licking, the leader spoke. His voice was a bass drum. Gloy! Goodness! Forgiveness! Education! Work-hard! Nyipir had tended the fire-lite uphoria in side his body. [1]

In the above extract, the author is using the leader's voice during that election period. The leader leads one opposition party in Kenya. His party participated during that election. He made the speech about the upcoming Kenya. At the time of the general election, Kenyans were on culture and globalization collation. As a result, the leader made his speech during the election process. In his speech, he used five words that help him to catch Kenyan attention. These are Glory, Goodness, Forgiveness, Education, and hard-working. Each idea is still the dream of many developing countries, like African nations. Kenyans were in ethnic conflict. Especially as Alice Wairimu Nderitu's book mentioned in December 2007, what appeared to have started as protests against perceived flawed results of the general elections assumed an ethnic dimension that quickly turns edgily. President Mwai Kibaki and Raila Odinga's supporters engaged in an orgy of violence, pitting ethnic communities against each other, unprecedented by Kenyan standard. [3]

Some scholars associated positive thinking with optimism. Positive thinking is related with positive emotions and other constructs such as optimism, hope, joy and wellbeing. [11]

On the other hand, such kind of ethnic competition and conflict is about national resources, job opportunities, 
governmental positions, tenders, and contracts land. And also property access to opportunities, such as good educational institutions that were found in Kenya during that election period.

\subsection{Socialist Humanism in the Novel Dust}

As Abiye [2] discussed, Socialist Realism has a more positive outlook towards life as a result in the novel Dust, the author raised such a positive outlook. The author also mentioned questions related to infrastructure that build in the country by fundraising. This is also optimism for coming to prosperous Kenya.

Harambee! Harambee! A nation brought to ask in clarion call that had hauled steel across the land and built a rail way. The national summons- Response - a howled Eeehhhh [1]

As put on the above extract, 'Harambee' is a Swahili word that means stand together for the common goal of the nation. This togetherness brought a nation to ask what they deserved.

The other Optimism is showed in Dust is during the death of Tom Mboya. When he died, things in Kenya getting worst, there was migration also. As the author puts:

After Mboya, everything that could die in Kenya did, even school children standing in front of a hospital that the leader of the Nation had come to open. A central province was emptied of a people who were renamed cockroaches and 'beasts from the west'. [1]

Tom Mboya had a good vision for Kenya and Kenyans. As mentioned above, his death made everything worst. People attacked each other; ethnic-based conflict arose in Kenya. People, who were living peacefully before, flee to Nairobi from the West. The death of this man-made everything is worst than ever in Kenya. As a result, as the author discussed losing hope and the future is highly seen. All these things are solved by the other politicians who are giving hope to the citizens of Kenya.

Abiye [2] discussed that Socialist Realism deals more with a man than his problems. So humanism is having positive and constructive comment which helps a man. In another word, humanism is an ideology that believes in the value, freedom, and independence of human beings. For humanists, all human beings are born with moral value and have a responsibility to help each other lives better lives. In the next extract, the author gives much attention to children who live in Kenya.

.... sucheyes-turned inward silences othat when bodies started showing up mutilated and truly dead, the loudest protests were created out of whispers. To protect new postindependence citizen, children, like must new Kenya parents denying soul betrayals, Nyipir built illusions of another Kenya. [1]

On the above statement, new post-independence citizens are citizens of Kenya who live after independence and after the 2007 national election. The protesters tried their best to make and protect Kenyan citizens. Children and citizens must be protected in the new Kenya society. In the next extract, the author gives his Socialist Realism ideology by being concerned with humanity as a feature.

To protect new post independence citizen children, parents like him repainted illusion so far 'future Kenya', while shouting out words of the national anthem as if volume alone would recreate reality. Nyakua. Mouths, ears, and eyes shut, parents partitioned sorrow, purchased more silences and waited for the 'better Kenya 'to turn up. [1]

The author believes to build a new Kenya. The first thing was to eliminate national grief that occurred during the process of election and after it. There was a huge conflict in the country, so these conflicts end up with the death of citizens. There was a big sorrow. The only thing is protecting Kenyans. So the character Ajany wants to escape this problem by going to her art studio. She was thinking a lot about the problems however she couldn't do anything. The below extract discussed how she works on her canvas.

Ajany had turned and run into the art studio, retrieved last term' sun finished canvases and hardened paint. She could already heart hat sound of ocean waves, inside the waves; she saw the color yellow-white screaming at the color indigo blue.(Owuor's2014p. 52)

\subsection{Romanticism in the Novel Dust}

As Fikire [7] discussed, Socialist Realist portrays nature as bigger as and greater than they are. As a result, in the novel Dust, much attention gives to nature with romantic expressions. As discussed in the previous chapter romanticism needs exaggeration. Romanticism helps the author to escape from nature; hazards, poverty, migration, and corruption. Especially in Northern Kenya; Every time there is a disaster such as hunger, floods, and inter-ethnic clashes in the northern part of Kenya, the media reports numerous deaths. Kenyans in 'real Kenya' embark on campaigns to save the victims in the north. One such campaign is the 'Kenyans for Kenyans Initiative' that took place in 2011. [5]

So, it saw Kenyans coming together to contribute food for fellow Kenyans facing hunger in the northern part of the country.

The author says that the participation of Odidi and Ajani in music and painting helped them escape from embarrassing stories of hunger in the Northern lands.

Music and painting cancelled out memories of annual February humiliations when news stories of northern land famines arrived with portraits of emaciated, breast-baring, adorned citizens, and skeletons of livestock. They suffered a flurry of 'School Walks 'and 'Give-Your-Change-Save-a-Life' and 'Help the Poor Starving People Kenya' picnics. [1]

The author adds that Ajany, being reed-thin, small, dark, and bushy-haired with large slanted eyes, would be photographed and the photo used in the school newsletter to report on the hunger campaigns. Embarrassed, Ajany and Odidi would yearn for the end of the term to go back to Wuoth Ogik.

Continued; in the next extracts, they are some exaggerations narrated by the author. Selene, the character, is from England. And she came to Kenya to do her works with 
her Englishman husband, but she met with Aggrey Nyipir Oganda. And they went to a big house; that administered by England's before. As Roger B. Henkle [9] mentioned not only do the major characters play a crucial role in a given literary but also the minor characters play a good role if they are portrayed well by the author. As a result, Selene was a minor character, and in the house, she felt different. The author puts her feelings clearly in the extract with full of exaggeration.

If all houses had resident spirits, Selene knew the ones here regarded her as an invading entity. Her nails cut into her palms as she looked through the screen window in to the landscape, its sleight-of-hand mound over vast horizons. The winds slithered in through the doum palms. She slapped her arms, imagining insects. A sensation. [1]

In the above extract, nails turned into cut her palms, the horizon, the wind movement, and especially the way she slapped her arms by imagining insects. All these expressions are full of exaggerations. And the author continued, on the same page, ".... Kenya had given her the ability to wear the right face for the right time. " [1]

In this extract, the author shows much the England woman comfortable with the Kenyans. How could be the face of the woman changed? The face doesn't change when the persons need to change. So the above expression gives face another and abnormal function.

\subsection{Class-Ness in the Novel Dust}

As Robert Loss stated by mentioning John Lennon... those who are interested in understanding the class dynamics of contemporary capitalism need an optics of class and class struggle that seeks understandings of non-monolithic working-class cultures that exist materially at specific locations but are acted upon by international forces. [12]

So, Class ness is anther Socialist Realism feature in the novel. Giddens [8] defined class as Socio economic differences are between groups or individuals which create differences in their material prosperity and power. In the post-election violence in 2007-8 after the assassination of Tom Mboya, there was very a difficult time for some ethnic groups of society. In the novel there are extracts that helps for their searcher to support this Socialist Realism feature.

After Mboya, everything that could die in Kenya did, even school children standing in front of a hospital that the leader of the nation had come to open. A central province was emptied of people who were renamed cockroaches and "beasts from the West" [1]

There was displacement of people from certain regions; "central province was emptied of a people who were renamed cockroaches and 'beasts from the west'", West refers to the Lake Victoria region which is Tom Mboya's home ground. The same displacement is replicated during the post-election violence where people are chased from their homes and those who remain are cut up and burned.... Nyipir indicates the radio. "Down-country, they 'rechasing people from their homes. The ones who stay are being cut up and burned." [1]

There was mistrust between the community represented by
Nyipir, his family and allies, and the other communities. This mistrust has existed since independence. This mistrust does not only a rise from ethnic differences but also from differences in political and social classes.

A character like Nyipir's was conscious of this history. When the same displacement is repeated during the postelection violence, Nyipir felt that his community is targeted. As a result, having equality in his mind and he raised /provoked the targeted society. Then, he started his struggle against officials who implemented biased and mistreatment against the society. So, the author discussed about creating Socialist Society in every aspect of the country.

The year 1952 is a time when the Mau Mau rebellion broke out and the British regime declared a state of emergency in Kenya.... In a dinner to celebrate the outgoing governor, Mitchell, the topic that ensued was the Mau Mau under the sub theme KAR (4). During the uprising, numerous deaths of whites and Africans were reported. One of the instances is the murder of a white settler family and children in Aberd are Ranges.

While murders happened, the novel discloses the fear that gripped settlers despite thou their superiority. In the extract which stated later; discuss about the presence of class in the country Kenya.

Favorite rumor: insurrection.

Favorite fear: death of European.

The unspoken: loss of a nation, nowhere else to go

The fear: requiem fo $r$ an ideal

Selene thought: I told you so.

....... [1]

And the author also the narrator says Selene was not afraid of death because he had seen her close friends die, Selene had hoped that the entire infrastructure such as the railway system, public works, the water works and the city be blown up so that she could go back to England. Selene's fright depicts disquiet among the British settlers who were afraid of the Mau Mau insurgency. It explains that despite the superiority that the British settlers showed in suppressing the Africans, there were those that cowered for fear of dying and therefore they wished they could relocate to England.

The above death of the settlers is created by the question of equality; And also to avoid the superiority of the whites in Kenya.

Africans reacted sharply to discrimination and oppression policies by forming political organizations to protect their interests, especially the educated Africans and World War I and II ex-soldiers who demanded the abolition of the Kipande system, lower taxes, use of forest land and increase in education and title deeds for land owners according to D. N. Sifuna [14]. Sifuna further notes that in the 1940s, especially after the end of the Second World War, the country witnessed a steady growth in secondary and higher education that led to an emergence of elites at the national level. These elites were to provide a new strategy to political leadership. They started to ask for equality and they aimed to dream to establish class-ness society. And the elites who colonialists 
frustrated sought to overthrow the colonial system. Through the story of Hugh Bolton and Selene, Dust reveals the atrocious events that happened in colonial Kenya during the Mau Mau rebellion. Bolton was part of the settlers who desired that Britain should maintain its Kenya colony under all means. He was determined to remain in Kenya by exerting power saying, "Power is useless if it cannot be expressed (author's emphasis)" [1] Through Bolton, we learn how the colonial masters mistreated their African servants. So there was mistreatment against the Kenyans during the colonial period. The author discussed this mistreatment to show the main aim of her major characters.

\subsection{People-Ness in the Novel Dust}

In the novel, there was also another Socialist Realism aspect, people-ness. It means standing with the people against all odds. Socialist Realist authors use their character to teach, to preach and to transmit their own message to the reader/to the societies. These people-ness features can be expressed through different aspects. As Fikire [7] stated Socialist realism affirms life and heroic deeds of the proletariat, the peasantry and all the progressive elements, now that the parasite, the bourgeoisie, has been eliminated. For example, in Dust the major character fought against corrupt officials, against crime and against killers. This character was a student and then later he was a civil servant.

In the novel Odidi's story is presentation of the stories of individuals in Kenya who, after futile attempts to secure a nation -state free from corruption, end up with despair in their bowls. They resort to crime, die poor or are killed by the state for criticizing its dire leadership.

And also, parents like Nyipir, seeing Kenyans who criticized corruption and misrule suppressed, experience the illusion of a 'future Kenya'. Their mouths, ears and eyes were shut and they partitioned sorrow, purchased more silence and waited for better 'Kenya', which never turned up. [1]

Nyipir had warned Odidi against meddling in the affairs of the nation-state. In the novel there is an extract which mentioned about Nyipir's attitude.

Afterward, in the interlude of strokes from a hippo-leather whip that toreat Odidi's body, Nyipir implored, "the only... war you fight... is for what belongs to you. You can't live the songs of people who don't know your name."

...... (Owuor's2014. p. 10)

He had told him, "You do not sing the songs of the people who don't know you...". Nyipir's warning stemmed from his experience with the nation-state in 1969 when he was tortured. After Odidi was fired from Tich Lich Engineering Company, which he had founded with his friend, he went to the streets to petition people to standup against corruption and injustices that had become a norm in the society. With no means to survive and his mortgage recalled, Odidi got disillusioned and became a criminal.

However, Ajany Odidi's sister discussed about Odidi. He had died in what Ajany says came from heroic idealism ashed had been organizing the disenchanted outh to work for a different future for themselves and it was sad that the 'stupid' nation-state did not have the capacity to grasp Odidi's vision and instead destroyed him. In the novel:

.... Later.

She tells him a little about T. L. Associates Engineeringthat Odidi had left a legacy with his work in water. She tells him that Odidi's time with the gang came from heroic idealism. He had only been organizing the disenchanted youth to work for a different future for themselves. It is sad, she tells her father, that the stupid state did not have the capacity to grasp Odidi's vision and had instead destroyed him. [1]

On the above extract, Owuor's character, Odidi, tried his best to create and to have a good Kenya, as a citizen. However the state leaders were 'stupid' as his sister said. Odidi had a good vision for the people but the State killed him.

\subsection{Positive Hero in the Novel Dust}

As Rufus W. Mathewson [14] discussed the proper relationship between literature and society is unpredictable in a literary work. It mentioned the nature of value in literary judgment, and of the moral and social obligations of the writer. In this conglomerate, the positive her and his activities are a focal point.

In the novel Dust, the author has a unique and easily identified character, Odidi. The story narrates his story; how he died? Why he died? The simple answer is he died for his country. Being patriotic kills him. The researcher under this title narrates and tells to his reader about Odidi briefly. His braveness is seen at school, at his village, and at his work place.

Moses Odidi Oganda was eighteen years old, a fresh man in the University of Nairobi. He was study in engineering. After three semesters later, he traveled home to Wuoth Ogik. In their third evening as a family, Odidi Oganda brought in the AK-47 that Nyipir, his father, had given him five years ago (10). After he had this pistol, he threw the pieces at Nyipir feet, and then he starts chanting. This chanting gave him courage and confidence; and the reason why he started fight is positive and clear.... Aye, aye, aye... In ogo agree make my brother hungry, make In o talk... [1] In this extract Odidi was brave and reason able to fight against enemies of the people. And also this is a major step in renouncing again stone's fellow citizens. This part of the novel shows that patriotism greatly inspires whistle blowing against various problems of the society.

His heroic activity continued when he and his sister, Ajany, were at school break; their plotter of adventure. He decreed they should visit the forbidden, damask-stone cave to find the source of a stream they could hear but not see. But as it put later his sister was afraid and lacked courage as a result she tried to stop him.

\footnotetext{
.......

"No!" Ajany had stammered. "There is bad in there."

"How do you know?" Odidi scoffed.
} 


\section{"Akai-masays..."}

"we'll find water at the base." He had interrupted her. His words had separated and bounced back. Wa... Bassssss... Ter... Wa... Ssssss.... [1]

So Ajany had placed her hand in his and followed him to the cave entrance that opened into a hollowed - out higgledypiggledy. Finally they found human's bone. And they turn back from the cave.

In the story; the teamwork and a belief in the cause contribute to the effectiveness of guarding the society against civil mal practices. Dust demonstrates this sport, rugby. This sport activity needs determination, teamwork, and sacrifice, given the difficult tackles from the opposing team. So, his courage continued when he was joining his art school rugby team. He was the visible actor, winger. In a mission involving many other roles but they are back - stage actors.

For Odidi, his excellent success as a winger in national rugby fosters in him a high sense of patriotism:

... Before Jonah Lomu made it right to have large wingers, there was Shift at he Kenyan Winger, who carried the game into the face opponents, and who scored try after try after try while crowds chanting Shifta! Thump! Thump! Winger! Thump! Thump! And later, when he heard the Kenyan national anthem, felt it resound in his spirit, he had wept tears that traveled past his lips and reached the earth. [1]

Even his teammates and his funs give a new name for their new hero. They created song so worship for their new heroshifta! The Winger! Odidi found belonging, and Ajany, reflecting Odidi's glory.

Character Odidi who hails from Northern Kenya, an area that has been pretty much left to its own devices throughout Kenyan history, Owuor suggest a need to confront the region's marginalization. The writer achieves this by moving the Kenyan literary narrative tradition from the typical central province or Nyanza region to Turkana Country: a land that has never featured much in Kenya public and literary imaginaries. As it depicted on the above, after the winger had victory in the game where he was a key player, the national anthem sings.

The other heroic and patriotic activity is seen after the state sanctioned electric power sabotage; the managing director of national power company appears on television and sorrowfully announces:

... In sorrowfully tones he announced an imminent powershortage emergency and the enforcement of a powerrationing plan. As If by coincidence, obsolete diesel generators from Europe and Asia happened to be a broad cargoships on their way to Kenya. They would take care of the short fall in power at 3,000 percent above the usual cost. A company to administer the supply of power from these generators had already been registered.

....... [1]

But Odidi barged into the minister of energy's office son the next day. He was shouting. But the minister asked him to write a letter. Then he wrote a letter to the minister headed Acts of Treason against the People and Nation of Kenya, backed with data and evidence, dates and figures to oppose their idea. But they didn't give answer for his appeal; he circulated it to the dailies. It wasn't published.

And then he even records several statements with the police, and unsuccessfully seeks audience with the President on the matter. He run from office to office with a petition form for citizens to sign; he unluckily seeks help from NGOs; he is also spotted speaking on the road corners.

However, he didn't stop there rather he persuaded his fellow engineers in the company to resign and expose the rot, but this is countered by the members voting him out. As it put in the novel:

".....

The chair man called for a vote. We noted out Odidi. "Silence. "He was being difficult. Wouldn't listen. We're talking billions, man. Y' know? 'Musa lip ushes out his lower lips. [1]

His friend and mate, Musali, who purports to understand Kenya, and how to survive in a corrupt system tells Ajany, Odidi's sister, about the scandal. Musa lion his speech showed that Odidi was right, but they were wrong. If they have incorporated with him, they would lose their job, eventually they lose their life.

"This was big. Really big. When you see something like this, man, you say yes or you die, y 'know?"

AjanyreadsinMusali'sshiftinesstheextentofherbrother 'sisola tion. [1]

The above statement shows how Odidi was trying to publicize corrupt governors to justice. Finally in this situation Musali convicted, he admits being complicit in the crime: "We silted the dams. No choice. We have our money" [1].

So a sit discussed before all these Odidi's struggle was used as reflections on individuals who fashion themselves as martyrs and beginners who play in disrupting state oppression. On the above extracts, heroism and patriotic were related with different features in this novel. For example at school, at university and at working place were the major places which the character showed his strength however all these heroic activities end up with scarification of life.

\section{Conclusion and Recommendation}

This study has attempted to explore the implementation of Socialist Realism in selected Contemporary Anglophone Kenyan novels. Though Socialist realism is an outdated approach to novel writing at the moment, however, this study focuses on the Kenyan experience of employing it in very recent years and its re-emergence. In doing so, the researcher analyzed the distinct features of Socialist Realism that the Contemporary Anglophone Kenyan novel has made use of. Moreover, the issue of what implies the application of Socialist Realism in the novels has also been considered by investigating the grounds from which they need to employ the technique arises. The significance of utilizing Socialist Realism in the novels has also been stated. And for this study Socialist Realism was used as a theory and a method to analyze the Contemporary Anglophone Kenyan novels. 
The research has found out that, Socialist realist features set out in the theoretical framework, some features dominate in all the novels. And these are optimism, Socialist Humanism, Socialist Romanticism, Class-ness, People-ness, and positive hero.

These Socialist Realism features are discussed in the novel Dust. Optimism in Dust is discussed in a dream of changing Kenya as a whole. Humanism in the novel, Dust stated to keeping mass of the society safe. Romanticism features expressed to escape from the reality. And to take a break from the normal fictional life of the characters. Music and nature are used as an instrument to express Socialist Realism in the novel. The other aspect of Class-ness is stated in the novel Dust, Class-ness is stated between colonizers and colonized citizens. On the other hand, People-ness is discussed in the novel by characters that are being committed to their duty. In the novel, for building a great nation, Kenya. At last, the Positive hero in the novel is stated widely. The hero and heroine were both male and females. Such scarification were ended up with death in the novel Dust.

The researcher recommends future researchers take up a comparative study of Socialist Realists literary works, reemergency of Socialist Realism, and its current implementation among different contexts worldwide. And they try and see the similarities and differences between continents. And possibly this will enable researchers to see and discuss Socialist Realism and its current influence on worldwide literary trends.

\section{References}

[1] Yvonne Adhiambo Owuor (2014) "Dust” Knopf.

[2] Abiye Daniel (1986). Socialist Realism and its Implication for the African Writer. Addis Ababa University Press. Addis Ababa, Ethiopia.

[3] Alice Wairimu Nderitu (2018). Kenya Bridging Ethnic Divides. A Commissioner's experience on Cohesion and
Integration. Mdahalo Bridging Divides Limited. Nairobi, Kenya.

[4] A. I. Revyakin: (1959) Problematipichesko gov khudozhestvennoy literature, Uchpedgiz, Moscow,. p. 3.

[5] Boiyo Amos Burkeywo. (2015). Narrating Kenyan History through Fiction in Yvonne Owuor's Dust. University of Nairobi, Kenya.

[6] Clark, Katerina (1985). The Soviet Novel: History as Ritual; with a New Afterword by the Author: University of Chicago Press, Chicago, IL.

[7] Fikre Tolossa (1983). Realism in Amharic Literature (19081981). Bremen: Bremen University. PhD Dissertation.

[8] Giddens, A. (1995) Modernity and Self Identity; Cambridge: Polity.

[9] Hankle, Roger B. (1977) Reading the Novel: An Introduction to the Techniques Interpreting Fiction. New York; Harper \& Row Publisher.

[10] Herman Ermolaev (1977). The Soviet Literary Theories $1917-$ 1934: The Genesis of Socialist Realism, Octagon Books, New York.

[11] Mc Grath. (2004) The Burden of RA positive Survivors and hospice patients' reflection on maintaining a positive attitude to serious illness.

[12] Robert Loss (2016) John Lennon's 'Working Class Hero': Boundaries, Mobility, and Honesty.

[13] Rufus W. Mathewson (2000). The Positive Hero in Russian Literature. Northern Western University Press.

[14] Sifuna, Daniel Namusonge. (1993). "Nationalism and Decolonization." Themes in Kenyan History. Ed. William R. Ochieng. Nairobi: EAEP,. 186-199.

[15] Yonas Adamu Chernet, (2014). Political Satire in Abebe Tola's "Yabe Tokichaw Shimutochi" and "Yabe Tokichaw Mitsetochi" Essays International Journal of Literature and Arts, Vol. 2, No 6. 